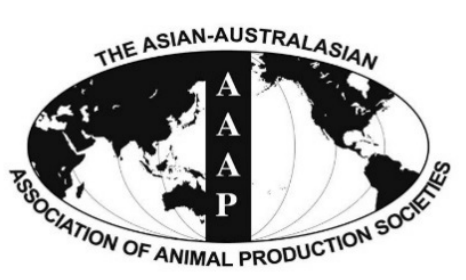

\title{
Influence of Quaternary Benzophenantridine and Protopine Alkaloids on Growth Performance, Dietary Energy, Carcass Traits, Visceral Mass, and Rumen Health in Finishing Ewes under Conditions of Severe Temperature-humidity Index
}

\author{
A. Estrada-Angulo, A. Aguilar-Hernández ${ }^{1}$, M. Osuna-Pérez, V. H. Núñez-Benítez', \\ B. I. Castro-Pérez, G. Silva-Hidalgo, G. Contreras-Pérez, A. Barreras ${ }^{1}$, A. Plascencia ${ }^{1, *}$, and R. A. Zinn ${ }^{2}$ \\ Veterinary and Animal Science School, University Autonomous of Sinaloa, Culiacán 80260, Sinaloa, México
}

\begin{abstract}
Twenty Pelibuey $\times$ Katahdin ewes $(35 \pm 2.3 \mathrm{~kg})$ were used to determine the effects of the consumption of standardized plant extract containing a mixture of quaternary benzophenanthridine alkaloids and protopine alkaloids (QBA+PA) on growth performance, dietary energetics, visceral mass, and ruminal epithelial health in heat-stressed ewes fed with a high-energy corn-based diet. The basal diet $(13.9 \%$ crude protein and $2.09 \mathrm{Mcal}$ of net energy [NE] of maintenance/kg of dry matter) contained $49.7 \%$ starch and $15.3 \%$ neutral detergent fiber. Source of QBA+PA was Sangrovit RS (SANG) which contains $3 \mathrm{~g}$ of quaternary benzophenathridine and protopine alkaloids per $\mathrm{kg}$ of product. Treatments consisted of a daily consumption of 0 or $0.5 \mathrm{~g}$ SANG/ewe. Ewes were grouped by weight and assigned to 10 pens ( 5 pens/treatment), with two ewes per pen. The experimental period lasted 70 days. The mean temperature humidity index during the course of this experiment was $81.7 \pm 1.0$ (severe heat stress). There were no treatment effects on water intake. Dry matter intake was not affected $(\mathrm{p}=0.70)$ by treatments, but the group fed SANG had a numerically $(11.2 \%)$ higher gain in comparison to the control group, SANG improved gain efficiency $(8.3 \%, \mathrm{p}=0.04)$, dietary NE $(5.2 \%, \mathrm{p}<0.01)$ and the observed-to-expected NE $(5.9 \%$, $\mathrm{p}<0.01)$. Supplemental SANG did not affect $(\mathrm{p} \geq 0.12)$ carcass characteristics, chemical composition of shoulder, and organ weights $(\mathrm{g} / \mathrm{kg}$ empty body weight) of stomach complex, intestines, and heart/lung. Supplemental SANG decreased liver weight $(10.3 \%, \mathrm{p}=0.02)$ and increased visceral fat $(16.9 \%, \mathrm{p}=0.02)$. Rumen epithelium of ewes fed SANG had lower scores for cellular dropsical degeneration $(2.08$ vs $2.34, \mathrm{p}=0.02)$, parakeratosis $(1.30 \mathrm{vs} 1.82, \mathrm{p}=0.03)$ and neutrophil infiltration $(2.08 \mathrm{vs} 2.86, \mathrm{p}=0.05)$ than controls. It is concluded that SANG supplementation helped ameliorate the negative effects of severe heat on growth performance of feedlot ewes fed high-energy corn-based diets. Improvement in energetic efficiency may have been mediated, in part, by anti-inflammatory effects of supplemental SANG and corresponding enhancement of nutrient uptake. (Key Words: Isoquinoline Alkaloids, Heat Stress, High-energy Diets, Feed Efficiency, Small Ruminants, Ruminal Epithelial)
\end{abstract}

\section{INTRODUCTION}

Heat stress negatively affects daily weight gain and/or feed efficiency of feedlot cattle. Additionally, cattle under

\footnotetext{
* Corresponding Author: A. Plascencia. Tel: +52-686-5636906 (111), Fax: +52-686-5636907, E-mail: aplas_99@yahoo.com

${ }^{1}$ Research Institute of Veterinary Sciences, University Autonomous of Baja California, Mexicali 21100, México.

2 Department of Animal Science, University of California, Davis, CA 95616, USA.

Submitted Apr. 5, 2015; Revised Aug. 12, 2015; Accepted Sept. 11, 2015
}

heat stress show impaired immune function, particularly as related to the digestive tract, resulting in increased risk of subclinical rumen acidosis (Uyeno, 2015). Antibiotic feed additives have benefited cattle under heat stress, helping to maintain a healthy ruminal epithelium through selective effects on microbial populations (Abdel-Samee, 1995). Niewold (2007) indicate that the effects of dietary supplementation with subtherapeutic levels of antimicrobials may be mediated through anti-inflammatory mechanisms. However, there is mounting concern regarding this practice and the development of antibiotic resistance and public 
health. Thus, considerable effort has been directed toward advancing the use of more "organic" alternatives. Among these, phytogenic compounds, such as isoquinoline alkaloids extracted from plants as Macleaya cordata, have shown promise as feed additives in broilers and pigs (Kantas et al., 2015). The quaternary benzophenanthridine and protopine alkaloids (QBA+PA) have both anti-inflammatory and immunomodulatory effects (Kosina et al., 2010). These alkaloids have selective effects on microbial growth along the digestive tract (Cushnie et al., 2014). In feedlot cattle, QBA+PA supplementation decreased ruminal ammonia $\mathrm{N}$ concentration (Plascencia and Zinn, 2014). Theoretically, all these effects are advantageous for ruminants under heat stress; however, research of the potential of QBA+PA as feed additives for cattle is limited and there is no information available on the effects of QBA+PA supplementation in finishing ruminants under conditions of severe ambient heat load. The aim of this experiment was to evaluate the effects of inclusion of standardized plant extract containing QBA+PA on growth performance, dietary energy, carcass traits and health of the ruminal epithelium in feedlot ewes fed finishing high-energy diets under conditions of severe temperature-humidity index.

\section{MATERIALS AND METHODS}

All animal management procedures were conducted within the guidelines of locally-approved techniques for animal use and care (NOM-051-ZOO-1995: humanitarian care of animals during mobilization of animals; NOM-062ZOO-1995: technical specifications for the care and use of laboratory animals. Livestock farms, farms, centres of production, reproduction and breeding, zoos and exhibition hall, must meet the basic principles of animal welfare; NOM024-ZOO-1995: animal health stipulations and characteristics during transportation of animals.

\section{Weather measurement and temperature humidity index estimation}

Climatic variables (ambient temperature and relative humidity) were obtained every hour from on-site weather equipment (Thermohygrometer Avaly, Mod. DTH880, Mofeg S.A., Zapopan, Jalisco, Mexico) throughout the experimental period. The temperature humidity index (THI) was calculated using the following formula: $\mathrm{THI}=0.81 \times T$ +RH (T-14.40)+46.40 (Hahn, 1999).

\section{Animals, diet and experimental design}

Twenty Pelibuey $\times$ Katahdin $(35 \pm 2.3 \mathrm{~kg}$ body weight, $\mathrm{BW})$ ewes were grouped by weight and assigned to 10 pens, with two ewes per pen. Pens had a size of $6 \mathrm{~m}^{2}$ with overhead shade, automatic waterers and $1 \mathrm{~m}$ fence-line feed bunks.
Two weeks before initiation of the experiment the ewes were treated for parasites (Tasasel 5\%, Fort Dodge, Animal Health, Mexico City, México) and injected with $1 \times 10^{6}$ IU vitamin A (Synt-ADE, Fort Dodge Animal Health, México). The source of QBA+PA used was Sangrovit-RS (SANG; Phytobiotics Futterzusatzstoffe GmbH, Eltville, Germany) which is a standardized plant extract preparation consisting of the QBA+PA extract from Macleaya cordata. The extract is a standardized to contain $3 \mathrm{~g}$ of quaternary benzophenathridine and protopine alkaloids per $\mathrm{kg}$ of product with a carrier based on rye flour plus salt. Treatments consisted of a basal diet (Table 1) supplemented to provide 0 or $0.5 \mathrm{~g} / \mathrm{ewe} / \mathrm{d}$ of SANG. Ewes were fed $0.3 \mathrm{~kg}$ (as fed basis) of the basal diet in the morning feeding $(0800 \mathrm{~h})$, and the remainder in the afternoon feeding. To ensure daily consumption, the total daily dosage of SANG was provided in the morning feeding as part of the complete mixed diet. This was accomplished by combining $50 \mathrm{~g}$ of SANG (handweighed using a precision balance, Ohaus, mod. SCOUT PRO SP401, Pine Brook, NJ, USA) with $30 \mathrm{~kg}$ of the basal diet in a 90-kg capacity paddle mixer (Leon Weill mixer, model 30910-7, Coyoacán, Mexico) and mixing for $10 \mathrm{~min}$ before feeding to ewes. Ewes were weighed before the morning meal on day 1 and day 70 (harvest). The initial BW was converted to shrunk body weight (SBW) by multiplying the weight by 0.96 to adjust for the gastrointestinal fill, and all lambs were fasted (feed, but not drinking water was withdrawn) for $18 \mathrm{~h}$ before recording the final BW. Ewes were allowed ad libitum access to dietary treatments. Daily

Table 1. Ingredients and composition of basal diet fed to ewe (\% of dry matter)

\begin{tabular}{lc}
\hline Item & $\begin{array}{c}\text { Diet composition } \\
(\% \text { DM basis })\end{array}$ \\
\hline Ingredient & 70.00 \\
Dry-rolled white corn & 8.00 \\
Soybean meal & 10.00 \\
Sudan grass hay & 7.50 \\
Molasses cane & 2.00 \\
Yellow grease & 2.50 \\
Trace mineral salt ${ }^{1}$ & \\
Chemical composition ${ }^{2}$ (\% DM basis) & 13.86 \\
Crude protein & 5.13 \\
Ether extract & 15.35 \\
NDF & 49.65 \\
Starch & \\
Calculated net energy (Mcal/kg of DM basis) & 2.05 \\
Maintenance & 1.38 \\
Gain & \\
\hline DM, dry matter; NDF, neutral detergent fiber; CP, crude protein. \\
${ }^{1}$ Mineral premix contained: CP, $50 \%$; calcium, $28 \%$; phosphorous, $0.55 \%$; \\
magnesium, $0.58 \%$; potassium, $0.65 \%$ NaCl, $15 \%$ vitamin A, 1,100 \\
IU/kg; vitamin E, 11 UI/kg. \\
${ }^{2}$ Based on tabular net energy (NE) values for individual feed ingredients \\
(NRC, 2007).
\end{tabular}


feed allotments to each pen were adjusted to allow minimal $(<5 \%)$ feed refusals in the feed bunk. The amounts of feed offered and of feed refused were weighed daily. Lambs were provided fresh feed twice daily at 0800 and 1400 hours. Feed bunks were visually assessed between 0740 and 0750 hours each morning, refusals were collected and weighed and feed intake was determined. Water consumption was measured daily at $0700 \mathrm{~h}$ by dipping a graduated rod into the tank drinker (one watering tank for each pen). Once the measure was taken, the remaining water was drained, and the tanks were refilled with fresh water.

\section{Laboratory analyses and calculations}

Feed samples were subject to the following analysis: Dry matter (oven drying at $105^{\circ} \mathrm{C}$ until no further weight loss; method 930.15; AOAC, 2000); ash (method 942.05; AOAC, 2000), Kjeldahl N (method 984.13; AOAC, 2000); aNDFom (Van Soest et al., 1991, corrected for neutral detergent fiber (NDF)-ash, incorporating heat stable $\alpha$-amylase [Ankom Technology, Macedon, NY, USA] at $1 \mathrm{~mL}$ per $100 \mathrm{~mL}$ of NDF solution [Midland Scientific, Omaha, NE, USA]); and starch (method 996.11; AOAC, 2000).

The estimations of dietary energetic and expected dry matter intake (DMI) were performed based on the estimated initial and final SBW. Average daily gains (ADG) was determined by subtracting the initial BW from the final BW and dividing that result by the number of days on feed. The efficiency of BW gain was computed by dividing ADG by the daily DMI. The estimation of expected DMI was determined based on observed ADG and average SBW according to the following equation: expected DMI, $\mathrm{kg} / \mathrm{d}=$ $\left(\mathrm{EM} / \mathrm{NE}_{\mathrm{m}}\right)+\left(\mathrm{EG} / \mathrm{NE}_{\mathrm{g}}\right)$, where $\mathrm{EM}$ (energy required for maintenance, $\mathrm{Mcal} / \mathrm{d}=0.056 \times \mathrm{SBW}^{0.75}(\mathrm{NRC}, 1985), \mathrm{EG}$ (energy gain, $\mathrm{Mcal} / \mathrm{d})=0.276 \times \mathrm{ADG} \times \mathrm{SBW}^{0.75}(\mathrm{NRC}, 1985)$, and $\mathrm{NE}_{\mathrm{m}}$ and $\mathrm{NE}_{\mathrm{g}}$ are 2.05 and $1.38 \mathrm{Mcal} / \mathrm{kg}$, respectively (derived from tabular values based on the ingredient composition of the experimental diet; NRC, 1985). The coefficient (0.276) was estimated assuming a mature weight of $113 \mathrm{~kg}$ for Pelibuey $\times$ Kathdin (Estrada-Angulo et al., 2013). Dietary NE was estimated by means of the quadratic formula: $x=\left(-\mathrm{b}-\sqrt{b^{2}-4 a c}\right) / 2 \mathrm{c}$, where $x=\mathrm{NE}_{\mathrm{m}}, a=-0.41 \mathrm{EM}$, $b=0.877 \mathrm{EM}+0.41 \mathrm{DMI}+\mathrm{EG}$, and $c=-0.877 \mathrm{DMI}$ (EstradaAngulo et al., 2013).

\section{Carcass and visceral mass data}

After harvest, ewes were skinned, and the gastrointestinal organs were separated and weighed. After carcasses (with kidneys and internal fat included) were chilled in a cooler at $-2^{\circ} \mathrm{C}$ to $1^{\circ} \mathrm{C}$ for $48 \mathrm{~h}$, the following measurements were obtained: i) body wall thickness (distance between the 12th and 13th ribs beyond the ribeye, five inches from the midline of the carcass); ii) fat thickness perpendicular to the $M$. longissimus thoracis (LM), measured over the center of the longissimus muscle between the 12th and 13th rib; iii) LM surface area, measure using a grid reading of the cross sectional area of the longissimus muscle between 12th and 13th rib, and iv) kidney, pelvic and heart fat (KPH). The KPH was removed manually from the carcass, and afterwards weighed and reported as a percentage of the cold carcass weight (CCW) (USDA, 1982). Shoulders were obtained from the forequarter. The weights of shoulder were subsequently recorded. The shoulder composition was assessed using physical dissection by the procedure described by Luaces et al. (2008).

All tissue weights are reported on a fresh tissue basis. Organ mass was expressed as grams of fresh tissue per kilogram of final empty body weight (EBW). Final EBW represents the final full BW minus the total digesta weight. The stomach complex was calculated as the digesta-free sum of the weights of the rumen, reticulum, omasum and abomasum. The ruminal epithelial histology was evaluated on samples obtained from the rumen (cranial, dorsal, and ventral sac) immediately following evisceration. The fixation protocol of ruminal papillae was based upon methodology reported by Graham and Simmons (2005).

\section{Statistical analyses}

Performance (DMI, ADG, gain efficiency, observed dietary NE, observed-to expected dietary NE ratio, and observed-to-expected DMI ratio) and carcass data were analyzed as a randomized complete block design using pen as the experimental unit. The MIXED procedure of SAS (SAS Inst. Inc., Cary, NC, USA) was used to analyze variables, with hot carcass weight as a covariate when it represented a significant $(\mathrm{p} \leq 0.05)$ source of variation in analysis of carcass measures. Shoulder composition was analyzed as a general complete block design, including the effect of block $\times$ treatment interaction, together with the effect of cold carcass weight as covariate. When the covariate represented a non-significant $(\mathrm{p}>0.05)$ source of variation it was not included into the model. The analysis was realized using the MIXED procedure (SAS Inst. Inc., NC, USA). Visceral organ mass data were analyzed as a complete block design, including the effect of block $\times$ treatment interaction. The MIXED procedure of SAS (SAS Inst. Inc., USA) was used to analyze the variables. Histological changes to ruminal epithelium (edema or inflammation process) were evaluated based on degree changes (considering dropsical degeneration, neutrophil infiltration and parakeratosis), coded as $1=$ normal, $2=$ moderate, and $3=$ intense. Histological data were analyzed using analysis of variance, Kruskal-Wallis and Fisher's exact tests $(\alpha=0.05)$. Multiple test comparisons using least significance difference were performed among treatments. Differences were considered significant when the $p$-value was $\leq 0.05$, and tendencies were 
identified when the $\mathrm{p}$-value was $>0.05$ and $\leq 0.10$.

\section{RESULTS AND DISCUSSION}

The experiment was carried out from June to August of 2014, the minimum and maximum estimated THI were 64.50 and 104.20, respectively (Table 2). Daily maximal THI exceeded the threshold THI value of 74 (Mader et al., 2006) for every day of the 70-d study. Average daily THI was $81.7 \pm 0.97$. Pelibuey breeds and their crosses adapt well to elevated ambient temperatures (Romero et al., 2013). Nevertheless, based on THI code (normal THI $<74$; alert 75 to 79 ; danger 79 to 84 , and emergency $>84$ ), ewes were exposed, on a daily basis, to conditions of severe ambient heat load.

Treatment effects on growth performance and dietary energetics are shown in Table 3. Water intake averaged 7.3 $\mathrm{L} / \mathrm{d}$ and was not affected $(\mathrm{p}=0.19)$ by SANG supplementation. Based on NRC (2007) expected water intake was $6.1 \mathrm{~L} / \mathrm{d}$, where water intake, $\mathrm{L} / \mathrm{d}=$ $(1.25+0.18 \times$ average temperature $) \times \mathrm{DMI}$. This estimate is in good (95\%) agreement with measures for non-supplemented ewes, but is considerable less (75\%) than observed water intake of SANG supplemented ewes. There is no information related to the effects of supplementation of SANG on water intake. The effect of QBA+PA on water intake of ruminants has not been previously reported. However, the numeric increase is consistent with diuretic effects of $\mathrm{QBA}+\mathrm{PA}$ observed in rats (Zdarilova et al., 2008).

Dry matter intake averaged $0.890 \mathrm{~kg} / \mathrm{d}$ and was not affected $(\mathrm{p}=0.70)$ by treatments. This value is $24 \%$ lower than the average DMI of previous reports utilizing lambs with similar breeding and dietary NE concentration (RoblesEstrada et al., 2009; Estrada-Angulo et al., 2013). However, the observed marked depression in DMI was in close agreement with the expected reduction in intake (25\%) by feedlot lambs subjected to severe heat load (NRC, 1987).
Table 3. Effects of Sangrovit-RS supplementation $(0.5 \mathrm{~g} / \mathrm{head} / \mathrm{d})$ on growth-performance and dietary energy in ewes under hot environment fed with high-energy corn-based diet

\begin{tabular}{|c|c|c|c|c|}
\hline \multirow{2}{*}{ Item } & \multicolumn{2}{|c|}{ SANG intake $(\mathrm{g} / \mathrm{d})$} & \multirow{2}{*}{ SEM } & \multirow{2}{*}{$\begin{array}{c}\mathrm{p}- \\
\text { value }\end{array}$} \\
\hline & 0 & 0.5 & & \\
\hline Days on feed & 70 & 70 & & \\
\hline Water intake (L/pen) & 6.44 & 8.10 & 1.06 & 0.19 \\
\hline \multicolumn{5}{|l|}{ Body weight $(\mathrm{kg})^{1}$} \\
\hline Initial & 38.19 & 38.14 & 0.02 & 0.31 \\
\hline Final & 45.64 & 46.45 & 0.38 & 0.21 \\
\hline DM intake $(\mathrm{g} / \mathrm{d})$ & 880 & 895 & 26 & 0.70 \\
\hline DM intake (\% BW) & 2.11 & 2.12 & 0.05 & 0.85 \\
\hline $\operatorname{ADG}(g / d)$ & 107 & 119 & 6 & 0.20 \\
\hline Gain for feed & 0.121 & 0.133 & 0.002 & 0.04 \\
\hline \multicolumn{5}{|l|}{ Dietary NE (Mcal/kg) } \\
\hline Maintenance & 1.87 & 1.96 & 0.01 & $<0.01$ \\
\hline Gain & 1.23 & 1.31 & 0.009 & $<0.01$ \\
\hline \multicolumn{5}{|l|}{ Observed- to-expected NE } \\
\hline Maintenance & 0.91 & 0.96 & 0.005 & $<0.01$ \\
\hline Gain & 0.89 & 0.95 & 0.006 & $<0.01$ \\
\hline Observed-to-expected DMI ${ }^{2}$ & 1.10 & 1.06 & 0.007 & 0.012 \\
\hline
\end{tabular}

SANG, Sangrovit RS; SEM, standard error of mean; $p$, observed treatment effect; DM, dry matter; BW, body weight; ADG, average daily gains; NE, net energy; DMI, dry matter intake.

${ }^{1}$ The initial BW was reduced by $4 \%$ to adjust for the gastrointestinal fill, and all ewes were fasted (food but not drinking water was withdrawing) for $18 \mathrm{~h}$ before recording the final $\mathrm{BW}$.

${ }^{2}$ Observed-to-expected DMI is according to ADG and dietary NE concentration.

Even though daily gain was not statistically different (averaging $113 \mathrm{~g} / \mathrm{d}$ ), ewe that fed SANG had numerically higher gain $(11 \%)$ than controls. Under "normal" THI conditions, expected ADG for lambs (NRC, 1985) is about $0.270 \mathrm{~kg} / \mathrm{d}$. Previous reports (Robles-Estrada et al., 2009; Estrada-Angulo et al., 2013) using lambs of similar breeding observed ADG from 0.200 to $0.300 \mathrm{~kg} / \mathrm{d}$. Decreased in ADG is linked in part with reduced feed intake, as well as

Table 2. Ambient temperature (Ta), relative humidity (RH) and calculated temperature-humidity index (THI) registered every hour and expressed as a weekly average)

\begin{tabular}{lcllllllll}
\hline Week & ${\text { Mean } \mathrm{T}_{\mathrm{a}}\left({ }^{\circ} \mathrm{C}\right)}$ & Min $_{\mathrm{a}}\left({ }^{\circ} \mathrm{C}\right)$ & $\mathrm{Max} \mathrm{T}_{\mathrm{a}}\left({ }^{\circ} \mathrm{C}\right)$ & Mean RH $(\%)$ & Min RH $(\%)$ & Max RH $(\%)$ & Mean THI & Min THI & Max THI \\
\hline 1 & $33.10 \pm 1.6$ & $21.40 \pm 2.0$ & $41.10 \pm 1.0$ & $48.20 \pm 8.8$ & $16.00 \pm 12.0$ & $92.00 \pm 10.9$ & $82.20 \pm 8.3$ & $64.50 \pm 2.6$ & $104.20 \pm 4.3$ \\
2 & $31.80 \pm 1.4$ & $20.89 \pm 1.0$ & $39.51 \pm 1.3$ & $49.60 \pm 3.4$ & $24.29 \pm 7.9$ & $92.43 \pm 3.0$ & $80.80 \pm 2.8$ & $64.89 \pm 0.7$ & $101.62 \pm 2.7$ \\
3 & $31.28 \pm 1.2$ & $21.50 \pm 0.9$ & $39.26 \pm 0.7$ & $51.48 \pm 7.4$ & $27.89 \pm 3.6$ & $79.29 \pm 17.3$ & $80.42 \pm 6.9$ & $65.79 \pm 0.7$ & $97.91 \pm 4.9$ \\
4 & $29.90 \pm 1.5$ & $23.10 \pm 0.9$ & $37.14 \pm 0.8$ & $69.14 \pm 7.7$ & $41.34 \pm 10.1$ & $93.40 \pm 5.0$ & $81.33 \pm 6.6$ & $68.71 \pm 1.4$ & $97.73 \pm 1.3$ \\
5 & $31.99 \pm 2.0$ & $23.93 \pm 0.5$ & $38.61 \pm 0.6$ & $58.74 \pm 5.9$ & $38.10 \pm 3.6$ & $91.57 \pm 5.1$ & $82.65 \pm 4.6$ & $69.41 \pm 0.4$ & $99.85 \pm 1.0$ \\
6 & $32.03 \pm 1.9$ & $24.81 \pm 1.6$ & $38.51 \pm 1.5$ & $59.15 \pm 7.2$ & $35.81 \pm 4.9$ & $84.43 \pm 6.5$ & $82.77 \pm 6.1$ & $70.23 \pm 2.2$ & $97.96 \pm 3.3$ \\
7 & $33.14 \pm 0.9$ & $23.69 \pm 1.4$ & $39.06 \pm 1.6$ & $51.49 \pm 5.1$ & $32.60 \pm 3.9$ & $87.31 \pm 3.8$ & $82.89 \pm 4.9$ & $68.61 \pm 1.8$ & $99.57 \pm 3.2$ \\
8 & $30.16 \pm 1.6$ & $23.84 \pm 0.9$ & $37.44 \pm 1.8$ & $60.76 \pm 9.9$ & $36.73 \pm 3.7$ & $87.36 \pm 2.8$ & $81.52 \pm 0.8$ & $69.18 \pm 0.8$ & $96.86 \pm 3.3$ \\
9 & $30.24 \pm 1.3$ & $24.57 \pm 1.1$ & $36.69 \pm 1.3$ & $65.19 \pm 6.5$ & $40.87 \pm 5.8$ & $88.74 \pm 1.8$ & $81.22 \pm 5.5$ & $70.46 \pm 1.2$ & $95.89 \pm 2.2$ \\
10 & $29.76 \pm 1.9$ & $20.93 \pm 1.1$ & $30.83 \pm 2.2$ & $65.18 \pm 7.8$ & $35.87 \pm 5.5$ & $77.64 \pm 1.6$ & $80.52 \pm 6.4$ & $65.69 \pm 1.6$ & $84.13 \pm 3.6$ \\
Mean & $31.34 \pm 1.3$ & $22.86 \pm 1.6$ & $37.82 \pm 2.8$ & $57.89 \pm 7.4$ & $32.95 \pm 8.0$ & $87.41 \pm 5.6$ & $81.67 \pm 1.0$ & $67.74 \pm 2.3$ & $97.57 \pm 5.4$ \\
\hline
\end{tabular}

${ }^{1} \mathrm{THI}=0.81 \times$ ambient temperature $+[$ (relative humidity $\times($ ambient temperature- -14.4$)]+46.4$. THI code (normal THI $<74$; alert 75 to $79 ;$ danger 79 to $84 ;$ and emergency $>84$ ). 
metabolic changes, during adaptation to "severe" ambient heat load.

SANG improved gain efficiency by $8.3 \%(p=0.04)$. Increased maintenance requirement in lambs due to metabolic demands to dissipate heat load, reduces energy available for weight gain (NRC, 2007). The estimation of dietary energy and the ratio of observed-to-expected DMI revealed differences in efficiency independent of ADG, providing important insight into potential treatment effects on the efficiency of energy utilisation of the diet. Compared to controls, dietary NE and observed-to-expected dietary NE ratio were $5.2 \%$ and $5.9 \%$ greater $(\mathrm{p}<0.01)$, and observed-toexpected DMI ratio was $4.4 \%$ lower $(\mathrm{p}<0.02)$ in lambs supplemented with SANG. Barajas et al. (2014) observed a $3.2 \%$ increase in dietary NE of feedlot bulls supplemented with $4 \mathrm{~g} \mathrm{SANG/d}$. An alternative approach for expressing SANG effects on animal energetics in the present experiment is to keep the net energy (NE) value of the diet constant and present treatment effects solely as a function of changes in the maintenance coefficient, as follows: $\mathrm{MQ}=\left(\mathrm{NE}_{\mathrm{m}} \times[\mathrm{DMI}-\right.$ $\left.\left.\left\{\mathrm{EG} / \mathrm{NE}_{\mathrm{g}}\right\}\right]\right) / \mathrm{SBW}^{0.75}$, where $\mathrm{NE}_{\mathrm{m}}$ correspond to the $\mathrm{NE}_{\mathrm{m}}$ of diet (Table 1), $\mathrm{EG}=276 \times \mathrm{ADG} \times \mathrm{SBW}^{0.75}$ and $\mathrm{SBW}$ is the average SBW. Accordingly, ambient heat load increased the maintenance coefficient of control and SANG supplemented ewes by $14.7 \%$ and $9.4 \%$, respectively. It was previously reported (Plascencia and Zinn, 2014) that supplemental SANG increased supply of non-ammonia $\mathrm{N}$ to the small intestine, as a consequence of a decreased ruminal feed protein degradation and increased microbial protein synthesis in cattle that were fed a high energy finishing diet. Even when the effects of SANG have been not evaluated on ruminal microorganisms in vivo, the reduction on peptide degradation and amino acid deamination could be attributed to the selective antimicrobial effects of SANG that could affect the high ammonia- producing bacteria, and/or by inhibition of aromatic amino acid decarboxylase (Drsta et al., 1996). While the increase on microbial protein synthesis could be a reflex of a decrease or the removing protozoa from the rumen by SANG supplementation. Therefore, decreases of the negative impact of high temperatures on energy efficiency may be also partially explained by improves on protein efficiency.

There were no treatment effects $(\mathrm{p} \geq 0.12)$ on carcass characteristics and chemical composition of shoulder (Table 4). Barajas et al. (2014) also did not observe an effect of supplemental SANG on carcass characteristics of finishing bulls. Likewise, supplemental SANG did not affect carcass characteristics of pigs (Boddington and McOrist, 2011) or breast muscle weight of broilers (Zduńczyk et al., 2010).

There were no supplemental SANG effects on weights (g/kg EBW) of stomach complex, intestines, and heart/lung (Table 5). However, SANG decreased liver weight (10.3\%, p $=0.02)$, and increased visceral fat $(16.9 \%, p=0.02)$. To our
Table 4. Effects of SANGROVIT-RS supplementation $(0.5$ $\mathrm{g} / \mathrm{head} / \mathrm{d}$ ) on carcass characteristics and shoulder composition in ewes under hot environment fed with high-energy corn-based diet

\begin{tabular}{|c|c|c|c|c|}
\hline \multirow{2}{*}{ Item } & \multicolumn{2}{|c|}{ SANG intake $(\mathrm{g} / \mathrm{d})$} & \multirow{2}{*}{ SEM } & \multirow{2}{*}{ p-value } \\
\hline & 0 & 0.5 & & \\
\hline$\overline{\mathrm{HCW}}(\mathrm{kg})$ & 26.45 & 27.05 & 0.29 & 0.21 \\
\hline Dressing percentage & 57.95 & 58.25 & 0.43 & 0.64 \\
\hline CCW (kg) & 25.88 & 26.56 & 0.28 & 0.17 \\
\hline $\mathrm{LM}$ area $\left(\mathrm{cm}^{2}\right)$ & 15.41 & 15.55 & 0.35 & 0.76 \\
\hline Fat thickness (mm) & 5.71 & 5.32 & 0.30 & 0.41 \\
\hline KP fat $(\%)$ & 2.40 & 2.76 & 0.34 & 0.50 \\
\hline Body wall thickness (mm) & 20.3 & 23.1 & 0.79 & 0.06 \\
\hline \multicolumn{5}{|l|}{ Shoulder composition $(\mathrm{g} / \mathrm{kg})$} \\
\hline Muscle & 615 & 612 & 0.96 & 0.83 \\
\hline Fat & 192 & 205 & 14.2 & 0.56 \\
\hline Bone & 182 & 178 & 5.2 & 0.29 \\
\hline
\end{tabular}

SANG, Sangrovit RS; SEM, standard error of mean; $p$, observed treatment effect; LM, longissimus muscle; HCW, hot carcass weight; $\mathrm{CCW}$, cold carcass weight; KP, kidney and pelvic.

knowledge, no information is available related to the effects of supplementation of SANG on visceral mass of ruminants. In a previous report (Jankowski et al., 2009), supplemental SANG decreased $(11.1 \%)$ the liver mass in broilers. The basis for increased visceral fat with SANG supplementation is not clear. Previously (Plascencia and Zinn, 2014), supplemental SANG increased ruminal acetate molar concentration, and increased ruminal acetate may contribute to greater visceral fat deposition (Smith and Crouse, 1984).

The score for dropsical degeneration $(2.08$ vs $2.34, \mathrm{p}=$ $0.02)$, parakeratosis $(1.30$ vs $1.82, \mathrm{p}=0.03)$ and neutrophil infiltration $(2.08$ vs $2.86, \mathrm{p}=0.05)$ were lower for SANG than for controls. This scores means that rumen epithelium of ewes fed SANG showed less inflammation than that of

Table 5. Effects of Sangrovit-RS supplementation $(0.5 \mathrm{~g} / \mathrm{head} / \mathrm{d})$ visceral organ mass in ewes under hot environment fed with highenergy corn-based diet

\begin{tabular}{|c|c|c|c|c|}
\hline \multirow{2}{*}{ Item } & \multicolumn{2}{|c|}{ SANG intake $(\mathrm{g} / \mathrm{d})$} & \multirow{2}{*}{ SEM } & \multirow{2}{*}{ p-value } \\
\hline & 0 & 0.5 & & \\
\hline \multicolumn{5}{|l|}{ Organ weight (g/kg EBW) } \\
\hline Stomach complex & 30.14 & 33.39 & 1.35 & 0.12 \\
\hline Intestines & 48.03 & 49.60 & 2.20 & 0.62 \\
\hline Liver & 17.05 & 15.29 & 0.44 & 0.02 \\
\hline Heart/lungs & 24.61 & 24.98 & 0.66 & 0.69 \\
\hline Visceral fat & 40.20 & 48.42 & 2.17 & 0.02 \\
\hline \multicolumn{5}{|l|}{$\begin{array}{l}\text { Histological changes of } \\
\text { ruminal epithelium }\end{array}$} \\
\hline Dropsical degeneration & 2.34 & 2.08 & 0.27 & 0.51 \\
\hline Neutrophil infiltration & 2.86 & 2.08 & 0.25 & 0.05 \\
\hline Parakeratosis & 1.82 & 1.30 & 0.15 & 0.03 \\
\hline
\end{tabular}

SANG, Sangrovit-RS; SEM, standard error of mean; $p$, observed treatment effect; EBW, empty body weight.

${ }^{1}$ Histological changes were coded as $1=$ normal, $2=$ moderated, and $3=$ intense. 
controls. Similarly, supplementation of QBA and PA mixtures improved gut health by increasing villi height, villi width, villi height:crypt-depth ratio and surface area of jejunum in broilers under conditions of high ambient heat load (Reansoi, 2002). Likewise, the anti-inflammatory effects of SANG have been reported previously (Kosina et al., 2010), and appears to be more pronounced in animals under conditions that contribute to greater risk of inflammation. Considering that the proportion of soluble sugars and fiber in basal diet $(49.7 \%$ and $15.3 \%$, respectively, Table 1) and the duration of the finishing period (70 days) the risk factor of presentation of subacute acidosis was high (NRC, 2007), and in ruminants, sub-acute acidosis is a primary cause of inflammatory processes in ruminal rumen epithelial tissue (Plaizier et al., 2012). Niewold (2007) suggested that the effects of growth promoters maybe mediated through anti-inflamatory mechanisms. According to Vieira et al. (2008), this opens a new window of opportunity in the search for additives to promote animal growth. Therefore, it is possible that the search for alternatives to growth promoters does not necessarily mean a search for substances with the same mode of action as antimicrobials.

It is concluded that SANG supplementation helped ameliorate negative effects of severe ambient heat load on dietary energetics of ewes fed a high-energy finishing diet, resulting in improved gain efficiency. This effect may have been mediated, in part, by anti-inflammatory effects of supplemental SANG and corresponding enhancement of nutrient uptake.

\section{CONFLICT OF INTEREST}

We certify that there is no conflict of interest with any financial organization regarding the material discussed in the manuscript.

\section{REFERENCES}

Abdel-Samee, M. M. 1995. Using some antibiotics and probiotics for alleviating heat strees on growing and doe rabbits in Egypt. World Rabbit Sci. 3:107-111.

AOAC. 2000. Official Methods of Analysis. 17th edn. Association Official Analytical Chemists. Gaithersburg, MD, USA.

Barajas, R., B. J. Cervantes, I. Rogge, A. Camacho, and L. R. Flores. 2014. Influence of Macleaya cordata preparation on feedlot performance and carcass characteristics of finishing bulls. J. Anim. Sci. 92(E-Suppl. 2):771 (Abstr.).

Boddington, M. and S. McOrist. 2011. Successful amino acid sparing activity by finisher feed supplementation with sanguinarine alkaloids (Sangrovit ${ }^{\circledR}$ ). Proc. 5th Asian Pig Vet. Soc. Congress. Pattaya, Thailand.

Cushnie, T. P., B. Cushnie, and A. J. Lamb. 2014. Alkaloids: An overview of their antibacterial, antibiotic-enhancing and antivirulence activities. Int. J. Antimicrob. Agents 44:377-386.
Drsata, J., J. Ulrichova, and D. Walterova. 1996. Sanguinarine and chelerythrine as inhibitors of aromatic amino acid decarboxylase. J. Enzyme Inhib. 10:231-237.

Estrada-Angulo, A., Y. S. Valdés, O. Carrillo-Muro, B. I. CastroPérez, A. Barreras, M. A. López-Soto, A. Plascencia, H. DávilaRamos, F. G. Ríos, and R. A. Zinn. 2013. Effects of feeding different levels of chromium-enriched live yeast in hairy lambs fed a corn-based diet: Effects on growth performance, dietary energetics, carcass traits and visceral organ mass. Anim. Prod. Sci. 53:308-315.

Graham, C. and N. L. Simmons. 2005. Functional organization of the bovine rumen epithelium. Am. J. Physiol. Regul. Integr. Comp. Physiol. 288:173-181.

Hahn, G. L. 1999. Dynamic responses of cattle to thermal heat loads. J. Dairy Sci. 82(Suppl. 2):10-20.

Jankowski, J., Z. Zduńczyk, J. Juśkiewicz, K. Kozlowski, A. Lecewicz, and H. Jeroch. 2009. Gastrointestinal tract and metabolic response of broilers to diets with the Macleaya cordata alkaloid extract. Archiv fur Geflügelkunde 73:95-101.

Kantas, D., V. G. Papatsiros, P. D. Tassis, L. V. Athanasiou, and E. D. Tzika. 2015. The effect of a natural feed additive (Macleaya cordata), containing sanguinarine, on the performance and health status of weaning pigs. Anim. Sci. J. 86:92-98.

Kosina, P., J. Gregorova, J. Gruz, J. Vacek, M. Kolar, M. Voguel, W. Ross, K. Naumann, V. Simanek, and J. Ulrichova. 2010. Phytochemical and antimicrobial characterization of Macleaya cordata herb. Fitoterapia 81:1006-1012.

Luaces, M. L., C. Calvo, B. Fernández, A. Fernández, J. Viana, and L. Sánchez. 2008. Predicting equation for tisular composition in carcass of Gallega breed lambs. Arch. Zootec. 57:3-14.

Mader, T. L., M. S. Davis, and T. Brown-Brandl. 2006. Environmental factors influencing heat stress in feedlot cattle. J. Anim. Sci. 84:712-719.

Niewold, T. A. 2007. The nonantibiotic anti-inflammatory effect of antimicrobial growth promoters, the real mode of action? A hypothesis. Poult. Sci. 86:605-609.

NRC. 1985. Nutrient Requirement of Sheep. 6th Rev. edn. National Academy Press, Washington, DC, USA.

NRC. 1987. Predicting Feed Intake of Food-Producing Animals. National Academy Press, Washington, DC, USA.

NRC. 2007. Nutrient Requirement of Small Ruminant. Sheep, Goats, Cervids, and New World Camelids. National Academy Press, Washington, DC, USA.

Plaizier, J. C., E. Khafipour, S. Li, G. N. Gozho, and D. O. Krause. 2012. Subacute ruminal acidosis (SARA), endotoxins and health consequences. Anim. Feed Sci. Technol. 172:9-21.

Plascencia, A. and R. A. Zinn. 2014. Rumen is not a "Black box". Proc. Conference Scientific Seminar Managing Ruminant Nutrition- torn between High Performance and Welfare. Eltville, Germany. File:///C:/Users/Alejandro/Downloads/Phytobiotics\% 20conference\%20manuscript_Plascencia\%20and\%20Zinn\%20 8-20-2014\%20(2).pdf Accessed January 5, 2015.

Reansoi, A., Y. Ruangpanit, and S. Attamangkune. 2015. Effect of quaternary benzophenantridine and protopine alkaloids on growth response and gut health of broiler under hot climate management. Annual Conference Kasetsart, Bankok, Thailand. http://www.annualconference.ku.ac.th/cd53/02_019_O253.pdf Accessed January 5, 2015.

Robles-Estrada, J. C., A. Barreras-Serrano, G. Contreras, A. Estrada-Angulo, J. F. Obregón, F. G. Ríos, A. Plascencia, and F. 
G. Rios. 2009. Effect of two $\beta$-adrenergic on finishing performance and carcass characteristics in lambs fed allconcentrate diets. J. Appl. Anim. Res. 36:33-36.

Romero, R. D., A. Montero-Pardo, H. H. Montaldo, A. D. Rodriguez, and J. Hernández-Cerón. 2013. Differences in body temperature, cell viability, and HSP-70 concentrations between Pelibuey and Suffolk sheep under heat stress. Trop. Anim. Health Prod. 45:1691-1696.

SAS. 2004. User's Guide: Statistics, version 9. SAS Inst. Cary, NC, USA.

Smith, S. B. and J. D. Crouse. 1984. Relative contributions of acetate, lactate and glucose to lipogenesis in bovine intramuscular and subcutaneous adipose tissue. J. Nutr. 114:792-800.

USDA. 1982. Official United States Standards for Grades of Carcass Lambs, Yearling Mutton and Mutton Carcasses. Agriculture Marketing Service, Washington, DC, USA.

Uyeno, Y. 2015. Selective inhibition of harmful microbes. In: Ruminant Microbiology: From Evolution to Revolution (Eds. A. K. Puniya, R. Singh, and D. N. Kamra). Springer India, New Delhi, India. pp. 199-212.
Van Soest, P. J., J. B. Robertson, and B. A. Lewis. 1991. Methods for dietary fiber, neutral detergent fiber, and nonstarch polysaccharides in relation to animal nutrition. J. Dairy Sci. 74: 3583-3597.

Vieira, S. L., O. A. Oyarzabal, D. M. Freitas, J. Berres, J. E. M. Pena, C. A. Torres, and J. L. B. Coneglian. 2008. Performance of broilers fed diets supplemented with sanguinarine-like alkaloids and organic acid. J. Appl. Poult. Res. 17:128-133.

Zdarilova, A., E. Vrublova, J. Vostalova, B. Klejdus, D. Stejskal, J. Proskova, P. Kosina P, A. Svobodova, R. Vecera, J. Hrbac, D. Cernochova, J. Vicar, J. Ulrichova, and V. Simanek. 2008. Natural feed additive of Macleaya cordata: safety assessment in rats a 90-day feeding experiment. Food Chem. Toxicol. 46: 3721-3726.

Zduńczyk, Z., R. Gružauskas, J. Juśkiewicz, A. Semaškaitė, J. Jankowski, I. Godycka-Kłos, V. Jarule, A. Miezeliene, and G. Alencikiene. 2010. Growth performance, gastrointestinal tract responses, and meat characteristics of broiler chickens fed a diet containing the natural alkaloid sanguinarine from Macleaya cordata. J. Appl. Poult. Res. 19:393-400. 